\title{
Investigation of BK/JC Polyomavirus Presence in Infertile Male Patients
}

\section{Infertil Erkek Hastalarda BK/JC Polyomavirüs Varlıg̃ının Araștırılması}

\author{
Fatma ESENKAYA TAȘBENT'(iiD), Mehmet ÖZDEMIR²(IID), Hakan Hakkı TAȘKAPU³(iiD), Bahadır FEYZiOG̃LU²(iD) \\ ${ }^{1}$ Department of Medical Microbiology, Necmettin Erbakan University, Faculty of Medicine, Konya, Turkey \\ ${ }^{2}$ Department of Medical Microbiology, Division of Medical Virology, Necmettin Erbakan University, Faculty of Medicine, \\ Konya, Turkey \\ ${ }^{3}$ Department of Urology, Necmettin Erbakan University, Faculty of Medicine, Konya, Turkey
}

Cite this article as: Esenkaya Taşbent F, Özdemir M, Taşkapu HH, Feyzioğlu B. Investigation of BK/JC polyomavirus presence in infertile male patients. FLORA $2021 ; 26(1): 135-41$.

\begin{abstract}
Introduction: Infertility is a common medical condition that is frequently encountered worldwide. The most common diagnosis of male infertility is idiopathic, accounting for $30 \%$ of the cases. Worldwide, infections are another important cause of infertility. The present study aimed to investigate whether BK polyomavirus (BKV) and JC polyomavirus (JCV) are associated with male infertility.

Materials and Methods: From a university hospital, 80 semen and 80 urine samples were collected from men who applied to the infertility clinic and diagnosed as idiopathic infertility. As a control group, 60 semen and 60 urine samples were taken from healthy males who had fathered children. The detection of BKV and JCV was performed by multiplex real-time PCR.

Results: JCV positivity was $62.5 \%$ (50/80) for urine and 40\% (32/80) for semen in the infertile group. In the control group, JCV positivity was $38.3 \%(23 / 60)$ for urine and $35 \%(21 / 60)$ for semen. Only one patient of the control group had BKV positivity in urine and semen. The difference of JCV positivity in urine between infertile males and control group wasstatistically significant $(p=0.005)$. In addition, mean viral DNA load of JCV was found significantly higher compared to the control group in both urine and semen samples $(p<0.0001$ and $p=0.002$, respectively).

Conclusion: These results can be an important finding in elucidating the etiology of idiopathic infertility.

Key Words: Polyomavirus; Male infertility; PCR; JC virus
\end{abstract}




\title{
Öz
}

\section{İnfertil Erkek Hastalarda BK/JC Polyomavirüs Varlıg̃ının Araștırılması}

\author{
Fatma ESENKAYA TAȘBENT ${ }^{1}$, Mehmet ÖZDEMiR² ${ }^{2}$ Hakan Hakkı TAȘKAPU³ , Bahadır FEYZiOG̃LU²
}

\footnotetext{
${ }^{1}$ Necmettin Erbakan Üniversitesi, Meram Tıp Fakültesi, Tıbbi Mikrobiyoloji Anabilim Dalı, Konya, Türkiye

${ }^{2}$ Necmettin Erbakan Üniversitesi, Tıp Fakültesi, Tıbbi Mikrobiyoloji Anabilim Dalı, Tıbbi Viroloji Bilim Dalı, Konya, Türkiye

${ }^{3}$ Necmettin Erbakan Üniversitesi, Tıp Fakültesi, Üroloji Anabilim Dalı, Konya, Türkiye
}

Giriş: Infertilite, tüm dünyada sıklıkla karşılaşılan yaygın bir medikal durumdur. Idiopatik infertilite, erkek infertilitesinin en sık karşılaşıIan sebebi olup, tüm vakaların \%30'nu oluşturmaktadır. Infeksiyonlar ise infertilitenin diğer önemli sebeblerindendir. Bu çalışmada BK polyomavirüs (BKV) ve JC polyomavirüs (JCV)'ün erkek infertilitesi ile ilişkisinin araştırılması amaçlanmıştır.

Materyal ve Metod: Bir üniversite hastanesi infertilite kliniğine başvuran ve idiopatik infertilite tanısı alan erkeklerden, 80 idrar ve 80 semen örneği toplandı. Kontrol grubu olarak çocuk sahibi olmuş 60 sağlıklı erkeğe ait idrar ve semen örnekleri çalışmaya dahil edildi. $B K V$ ve JCV varlığı, klinik örneklerde gerçek zamanlı polimeraz zincir reaksiyonu ile araştıııldı.

Bulgular: Infertil hasta grubunda JCV pozitifliği; idrar için \%62.5 (50/80), semen için \%40 (32/80) olarak bulundu. Kontrol grubunda, idrardaki JCV pozitifliği \%38.3 (23/60) iken, semende JCV pozitiflik oranı \%35 (21/60) olarak tespit edildi. BKV pozitifliğine ise sadece kontrol grubundaki bir hastanın idrar ve semeninde rastlandı. Idrardaki JCV pozitifliği açısından infertil grup ve kontrol grubu arasındaki fark istatiksel olarak anlamlı bulundu ( $p=0.005)$. Ayrıca JCV'nin ortalama viral DNA yükü, infertil hastaların hem idrar hem de semen örneklerinde kontrol grubuna kıyasla anlamlı oranda yüksek tespit edildi (sırasıyla $p<0.0001$ and $p=0.002$ ).

Sonuç: Bu sonuçların idiopatik infertilite etyolojisini aydınlatmada önemli bulgular olabileceği düşünüldü.

Anahtar Kelimeler: Polyomavirüs; Erkek infertilitesi; PCR; JC virüs

\section{INTRODUCTION}

Infertility is a common medical condition, with a prevalence of around 15\% in couples worldwide. Male infertility accounts for around $50 \%$ of the cases. After varicoceles, the most common diagnosis of male infertility is idiopathic, accounting for $25 \%$ of the cases ${ }^{[1,2]}$. Worldwide, infections are another important cause of infertility. Bacteria that affect the reproductive system can cause infertility by a number of methods ${ }^{[3,4]}$. Male infertility associated with Chlamydia trachomatis infection may be caused by sperm tract obstruction, epididymitis, prostatits or orchitis. In a similar way, it has been reported that Neisseria gonorrhoeae may cause male infertility with disseminated gonococcal infection ${ }^{[4,5]}$.

Viral infections as a case of male infertilty have been less well-studied. An impact on fertility is suggested, but not well understood ${ }^{[3,6]}$. Many viruses, including Epstein-Barr virus, human papillomavirus, cytomegalovirus, hepatitis $\mathrm{B}$ and $\mathrm{C}$ virus, human immunodeficiency virus (HIV), herpes simplex virus type 2 , human herpes virus type
6 are frequently present even in asymptomatic males, and they are often associated with poor sperm quality. The role of chronic viral infections as an etiologic factor of male infertility is not clear $^{[7,8]}$.

Human papillomaviruses are one of the most highly studied viruses as a cause of infertility. Some studies have reported that human papillomaviruses induce abnormal sperm count, low capacity for fertiliziation and production of anti-sperm antibodies ${ }^{[9]}$. On the other hand, the relationship between sperm parameters and the presence of cytomegalovirus DNA is unresolved, with some studies reporting no association, and other findings that sperm parameters and function are impaired by cytomegalovirus infection, and that a high concentration cytomegalovirus in ejaculate correlates with a transient decrease in spermatozoa motility. Herpes simplex virus has been associated with impaired semen quality and functions of the prostate and epididymis. HIV, hepatitis B and hepatitis C viruses in semen impair DNA integrity and sperm parameters (and 
in particular reduce forward motility). In some studies, azoospermia or oligozoospermia, hypogonadism, and orchitis have been noted in HIV-positive $\operatorname{men}^{[7,9,10]}$.

$\mathrm{BKV}$ and JCV are the original members of the human polyomaviruses family and ubiquitous among humans. Primary infections of BKV and JCV are usually asymptomatic and rarely seen as a distinct clinical disease. However, in immunosupressed patients these viruses can cause serious morbidity and mortality. BKV is associated with nephropathy after kidney transplantation and also associated haemorrhagic cystitis in allogenic stem cell recipients. JCV causes a fatal neurodegenerative disorder of the brain called the progressive multifocal leukoencephalopathy only in immunosuppressed individuals ${ }^{[6,11,12]}$.

$\mathrm{BKV}$ and $\mathrm{JCV}$ are viruses commonly found in the population. Therefore, general seroprevalence rates are high in societies. The prevalences of $\mathrm{BKV}$ and JCV vary, depending on demographic factors such as geographical region, age, sex, concomitant infection and immunity status. JCV exposure among different populations was reported to be $33 \%$ - 91\%, in various geographies and using different methods ${ }^{[13-15]}$.

In Turkey, Us et al. have investigated BKV antibody levels in 1123 healthy humans belonging to different age groups by a hemagglutination inhibition test. BKV seropositivity was found $61.4 \%$ in infants aged $0-11$ months, $65.3 \%$ in children aged $1-5$ years, and over $80 \%$ in the $\geq$ 6 years age group ${ }^{[16]}$. In a multinational study, Olsson et al. have found overall prevalence of anti-JCV antibody as 57.6\% in 10280 multiple sclerosis patients and the highest prevalence rates are reported for Turkey with $67.7 \%$. In the same study, the prevalence of JCV in Turkey was reported to be significantly higher in comparison to other countries ${ }^{[17]}$. Egli et al. have found BKV and JCV IgG seroprevalences of $82 \%$ and 58\% in healty blood donors by ELISA, while asymptomatic urinary shedding of these viruses has been detected in $7 \%$ for BKV and in 21\% for JCV by molecular assays ${ }^{[15]}$. Sroller et al. ${ }^{[14]}$ have reported anti-JCV and anti-BK seroprevalences of $57 \%$ and $69 \%$ in the general Czech population by ELISA.
The aim of this study was to investigate the frequency of BKV and JCV in infertile male patients by real time PCR in comparison with the control group and to determine whether there may be an association between polyomaviruses and infertility.

\section{MATERIALS and METHODS}

The study was approved by our university ethical committee with 2013/416 number, and informed consent was obtained from all participants. A long-term prospective study was undertaken in infertile men and a control group of healthy males. For the study, 80 semen and 80 urine samples were collected from infertile males who were attending the infertility clinic of our university hospital with low sperm concentration, decreased motility and abnormal sperm morphology. Control samples were 60 semen and 60 urine from healthy males who had fathered children.

Inclusion criteria were man aged 25-45 years living in rural and urban centers of Konya in the Internal Anatolia region of Turkey, who were non-smokers and who had not had previous urinary tract surgery. Men who were in the other age groups, from different geographical regions, or who had malignancy or were receiving immunomodulatory or immunosuppressive treatment were excluded. All patients in the study group had a diagnosis of idiopathic infertility; none had sexually transmitted infections, epididymitis, prostatitis, urinary tract infections or male accessory gland infection. Full urine analysis was normal in all infertile patients in the study group. Semen analysis of infertile patients was evaluated based on the WHO laboratory manual on the examination and proceessing of human semen. Oligoasthenopsermia was detected in all of the infertility cases ${ }^{[18]}$.

The presence of BKV and JCV was investigated by real-time polymerase chain reaction on clinical samples. DNA was isolated from $200 \mathrm{~mL}$ of semen and $200 \mathrm{~mL}$ of urine samples, using a commercial kit (High Pure Viral Nucleic Acid Kit, Cat- No. 03-003-248-001, Roche Applied Science, Mannheim, Germany) according to the manufacturer's instructions. DNA was stored at $-20^{\circ} \mathrm{C}$ until processing. In order to detect JCV 
and BKV; a LightMix $^{\circledR}$ kit was used for the polyomaviruses JC and BK (Cat.No-40-0203-32, Roche Diagnostics, Tibmolbiol) multiplex PCR in real-time was performed on the Roche Diagnostic LightCycler 2.0 Instrument.

Descriptive statistics were given for all variables. Chi square test was used when comparing categorical variables between the groups. T- test was used to compare means of age between the groups. Analysis was performed using SAS University Edition 9.4. A p value $<0.05$ was considered significant.

\section{RESULTS}

A total of 140 patients consented to participate in the study, 60 of them were in the control group consisting of fertile males, and the experimental group consisted of 80 infertile males. The median age of the 80 infertile males was 35 years (median 34.47 years), and that of the control group was 34 years (median 33.98). These differences were not statistically significant $(p=0.6)$. The distribution of two groups according to age is shown in Figure 1.

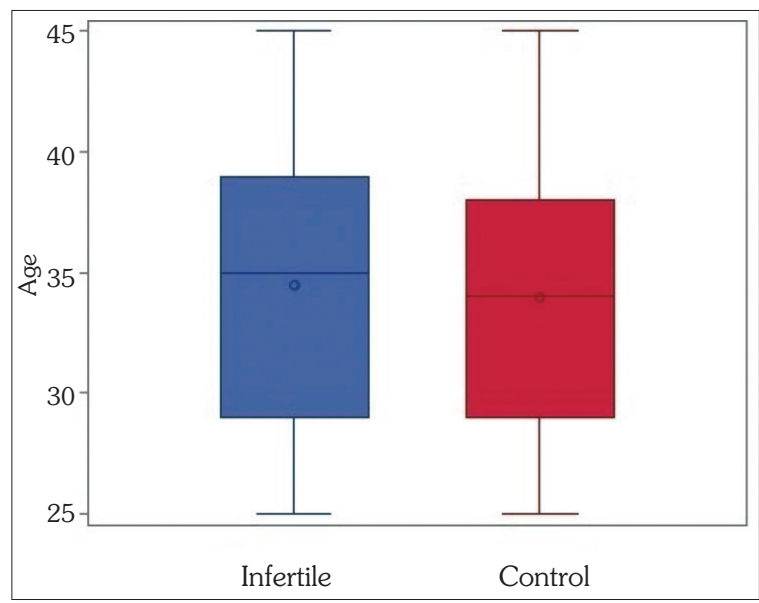

Figure 1. Distribution of age for infertile and control groups.
JCV positivity in urine was significantly higher in the infertile group $(62.5 \%)$ than in the control group $(38.3 \%)(\chi 2 \quad(1, \mathrm{n}=140)=8.0932, \mathrm{p}=$ $0.005)$. However, there was no significant difference in the rates of JCV positivity in semen between the infertile (40\%) and control (35\%) groups $(p=0.55)$

In the infertile group, none of the samples were positive for BKV DNA. Only one patient of the control group was $\mathrm{BKV}$ positive in urine and semen. Among the patients (infertile and control fertile patients), JCV prevalance was found $52.1 \%(73 / 140)$ in urine and $37.8 \%$ $(53 / 140)$ in semen samples. The majority of the JCV positivity in urine [68.5\% (50/73)] and in semen [60.4 (32/53)] belonged to infertile patients (Table 1).

Viral DNA load of JCV in urine and semen from infertile males was found $3.5 \times 10^{6} \mathrm{co}^{-}$ pies $/ \mathrm{mL}$ and $2.6 \times 10^{4}$ copies $/ \mathrm{mL}$, respectively. However, in the control group, viral load rates in positive patients were very low in both urine and semen with a value of $1.1 \times 10^{5}$ and 1.5 $\mathrm{x} 10^{3}$, respectively $(\mathrm{p}<0.0001$ and $\mathrm{p}=0.002$, Mann Whitney U test).

\section{DISCUSSION}

Male infertility is a big problem globally that is not always openly discussed. It is therefore important to determine the underlying etiology in the idiopathic infertility group. With a prevalence of $6 \%$ to $10 \%$, infections and the resulting inflammatory reactions within the male genital tract are among the main causes for male infertility. Chronic inflammation in the male reproductive system can affect spermatogenesis by reducing the number and motility of the sperm ${ }^{[19,20]}$

The possible association between male infertility and polyomaviruses is largely unknown, with there

Table 1. Prevelance of JCV and BKV positivity

\begin{tabular}{lcccccc} 
Polyomavirus & \multicolumn{2}{c}{ Infertile males } & \multicolumn{2}{c}{ Control group } & \multicolumn{2}{c}{$\begin{array}{c}\text { Total positivity } \\
\text { (Infertile and control) }\end{array}$} \\
\hline & $\begin{array}{c}\text { Urine } \\
(\mathrm{n}=\mathbf{8 0})\end{array}$ & $\begin{array}{c}\text { Semen } \\
(\mathrm{n}=\mathbf{8 0})\end{array}$ & $\begin{array}{c}\text { Urine } \\
(\mathrm{n}=\mathbf{6 0})\end{array}$ & $\begin{array}{c}\text { Semen } \\
(\mathrm{n}=\mathbf{6 0})\end{array}$ & $\begin{array}{c}\text { Urine } \\
(\mathrm{n}=\mathbf{1 4 0 )}\end{array}$ & $\begin{array}{c}\text { Semen } \\
(\mathrm{n}=\mathbf{1 4 0})\end{array}$ \\
\hline JCV positivite sample number (\%) & $50(\mathbf{6 2 . 5 \% )}$ & $32(40 \%)$ & $23(38.3 \%)$ & $21(35 \%)$ & $73(52.1 \%)$ & $53(37.8 \%)$ \\
BKV positivite sample number (\%) & $0(0 \%)$ & $0(0 \%)$ & $1(1.7 \%)$ & $1(1.7 \%)$ & $1(0.7 \%)$ & $1(0.7 \%)$
\end{tabular}


having been almost no studies on this topic. In this study, we investigated the presence of BKV and JCV DNA in sperm and urine of infertile male patients compared to healthy fertile males.

$\mathrm{BKV}$ and $\mathrm{JCV}$ are common viruses in the population. They generally infect the children in early years and remain latent in kidneys, urinary tracts and lymphoid tissues for long years. Reactivation and urinary shedding in immunocompetent individuals ranges from 0-62\%. Asymptomatic shedding of these viruses in the urine can be seen in both healthy subjects and immunosuppressed patients ${ }^{[21-23]}$.

Rota et al. from Turkey have investigated BKV and JCV positivity rate in a group of at-risk patients in Central Anatolia region that is same region with this study and reported respectively as $20 \%$ and $\% 11^{[24]}$. Caglı et al. have tested for Polyomavirus DNA in renal transplant recipients and healthy blood donors. BKV DNA and JCV DNA were found in $23.5 \%$ and $47.1 \%$ of transplant recipients at months 12 post-transplant, respectively. In healthy blood donors BKV DNA was not found, and JCV DNA was positive in $30 \%{ }^{[25]}$. In another study from Turkey, BKV and JCV positivity rates have been found as $33.4 \%$ and $4.3 \%$ respectively in immunosuppressive patients by multiplex real-time $\mathrm{PCR}^{[26]}$.

In the general population, JCV viruria is more common than BKV viruria. In contrast, in immunosuppressed patients, BK viruria is more common ${ }^{[27]}$. However in the literature, different rates have been reported in different studies. JCV seropositivity was higher in males, as previously reported although the reason behind this remains unknown. In a previous Turkish study,the prevalence of anti-JCV antibodies in multiple sclerosis patients has been found as 78.6\% in males and $64.1 \%$ infemales ${ }^{[28]}$. In a study conducted in India, the prevalence of JCV has beenconfirmed significantly higher in males ${ }^{[29]}$. In another multicenter study from different countries, the prevalence of JCV in patients with multiple sclerosis has been determined significantly higher in men $161.9 \%$ in men and 55.8\% in women). Looking at the data from Turkey in the same study, JCV prevalence rates have been reported as $80 \%$ in men and $63 \%$ in women ${ }^{[17]}$.
The clinical state caused by virus reactivation is often associated with the immune status of the person. However, Enam et al. have reported that JCV can cause distinct morphological changes, rapid division and prolonged life in cells. In some studies, it has been reported that JCV genomic sequences are detected in various tumors, particularly colon cancer and several types of brain tumor $^{[26,30,31]}$. Polyomavirus infections have been proposed as candidate etiological agents in some of diseases with unknown etiologies, and there have been few studies of these viruses as a cause of infertility ${ }^{[26]}$.

Seroprevalence rates in adult populations vary widely, from less than $20 \%$ to up to $90 \%$, depending on the demographic characteristics, the geographic area, ethnic groups, age groups and polyomaviruses strains ${ }^{[21]}$. In a multicenter study involving several countries from Europe, Asia and Africa, JCV sequences in semen have been investigated by PCR and the overall prevalence of JCV in semen samples have been found to be $27.6 \%$. In that study, which does not have any data from our country, it has been emphasized that the prevalence rates of $\mathrm{JCV}$ in semen and virus genotype vary according to geographical regions ${ }^{[13]}$.

We chose to investigate patients and controls resident in one region, Konya, in the internal Anatolia region of Turkey. However, the ethnic origins of the patients and controls were not fully analyzed. In this study, in order to test for possible infection of male genital system with BKV and $\mathrm{JCV}, 80$ urine samples and 80 semen samples from infertile males were analyzed, also control group was created from fertile men. Patients in the study group were previously analyzed for sexually transmitted infections. Infertile patients with sexually transmitted infections were excluded from the study. BKV DNA was not found in any infertile male samples, only one patient of the control group had BKV positivity. The prevalance of JCV was higher in urine samples from infertile men $(62.5 \%)$ than in the control group $(38.3 \%, p=$ $0.005)$, but there was no statistically significant difference in the prevalence of $\mathrm{JCV}$ in semen.In this regard, it is thought that our commercial PCR kit is produced for blood and urine samples and there may be standardization and optimization problems 
related to the study in semen. In addition, the mean viral load of JCV was higher in both the urine and semen of infertile men. When all samples were taken into consideration, both the mean viral load and the positivity rate in the semen were found to be lower than the urine. However, we believe that the detection of JCV DNA in semen is important for infertility.

Many microorganisms have been reported to bring about adverse changes in sperm parameters in vitro, but their in vivo potential to cause infertility is still controversial. In a study similar to ours, Comar et al. have found JCV positivity as 43.4\% in urine and $24.5 \%$ in semen of infertile men, compared with $28 \%$ and $11 \%$ in controls. They have also foundsimilar to ours that the prevalence of $\mathrm{JCV}$ in the semen was lower than that of the urine. They speculated that the presence of $\mathrm{JCV}$ DNA in sperm may affect egg fertilization and embryo development stages ${ }^{[6]}$.

When the literature is reviewed, it is reported that most microorganisms cause negative changes in sperm parameters in vitro, but their potential for causing infertility in vivo is still controversial. In their retrospective study, Garolla et al. have investigated the effects of HPV vaccine on fertility in infertile couples admitted to the infertility clinic and those who accepted and did not accept the HPV prophylactic vaccine. In the results of the study, it was reported that sperm motility and antisperm antibodies ameliorated in the vaccinated group and pregnancy and live birth rates were significantly higher in this group during the follow-up period. At the end of the study, it was suggested that HPV prophylactic vaccine increases the reproductive potential of infertile patients ${ }^{[32]}$.

In conclusion, using sensitive molecular assays, we detected an unexpectedly high prevalence of JCV from asymptomatic infertility patients compared to the control group. Furthermore, our finding that the JCV viral load was significantly higher in the study group than in the control group suggests that infertility may be associated with JCV. The possible role of $\mathrm{JCV}$ in the etiology of male infertility needs large multicenter studies. Furthermore, detailed cytological studies of the effect of JCV on the semen and urinary tract are needed at the cellular level. Certain studies on the presence of
$\mathrm{JCV}$ in the etiology of infertility will also guide the treatment of infertility, perhaps paving the way for $\mathrm{JCV}$ vaccine studies.

\section{ETHICS COMMITTEE APPROVAL}

The approval for this study was obtained from Necmettin Erbakan University, Clinical Research Ethics Committee (Decision No: 2013/416, Date: 17.05.2013).

\section{CONFLICT of INTEREST}

The authors declare that they have no conflict of interest.

\section{AUTHORSHIP CONTRIBUTIONS}

Concept and Design: MÖ, FET, HHT

Data Collection or Processing: FET, HHT

Analysis/Interpretation: MÖ, FET, HHT, BF

Literature Search: MÖ, HHT, BF

Writing: FET

Final Approval: MÖ, BF

\section{REFERENCES}

1. Gupta Narmada P, Kumar R. Lycopene therapy in idiopathic male infertility-a preliminary report. Int Urol Nephrol 2002;34(3): 369-72.

2. Pei J, Strehler E, Noss U, Abt M, Piomboni P, Baccetti B, et al. Quantitative evaluation of spermatozoa ultrastructure after acupuncture treatment for idiopathic male infertility. Fertil Steril 2005;84(1):141-7.

3. Souho $T$, Benlemlih M, Bennani B. Human papillomavirus Infection and fertility alteration: a systematic review. Harper DM, ed. PLoS One 2015;10(5):e0126936.

4. Pellati D, Mylonakis I, Bertoloni G, Fiore C, Andrisani A, Ambrosini $G$, et al. Genital tract infections and infertility. Eur J Obstet Gynecol Reprod Biol 2008;140(1):3-11.

5. Vander $H$, Prabha $V$. Evaluation of fertility outcome as a consequence of intravaginal inoculation with sperm-impairing microorganisms in a mouse model. I Med Microbiol 2015;64(4):344-7.

6. Comar M, Zanotta N, Croci E, Murru I, Marci R, Pancaldi $C$, et al. Association between the JC polyomavirus infection and male infertility. PLoS One 2012;7:e42880

7. Garolla A, Pizzol D, Bertoldo A, Menegazzo M, Barzon L, Foresta C. Sperm viral infection and male infertility: focus on HBV, HCV, HIV, HPV, HSV, HCMV, and AAV. J Reprod Immunol 2013;100(1):20-9.

8. Bezold G, Politch JA, Kiviat NB, Kuypers JM, Wolff H, Anderson $D J$. Prevalence of sexually transmissible pathogens in semen from asymptomatic male infertility patients with and without leukocytospermia. Fertil Steril 2007;87(5):1087-97. 
9. Gimenes F, Souza RP, Bento $J C$, Texeira JJV, Maria-Engler SS, Bonin MG, et al. Male infertility: a public health issue caused by sexually transmitted pathogens. Nat Rev Urol 2014;11(12):672-87.

10. Ochsendorf FR. Sexually transmitted infections: impact on male fertility. Andrologia 2008;40(2):72-5.

11. Al Barrak M, Al Fawaz T, Al Shehri M, Al Shahrani D, Elsiddiq $N$, Riyes MA. BK virus-induced severe hemorrhagic cystitis in non-transplant oncology patients: A case series. J Pediatr Infect Dis 2014;09(04):183-7

12. Xing J, Procop GW, Reynolds JP, Chiesa-Vottero A, Zhang $Y$. Diagnostic utility of urine cytology in early detection of polyomavirus in transplant patients. I Am Soc Cytopathol 2017;6(1):28-32.

13. Rotondo JC, Candian T, Selvatıcı R, Mazzoni E, Bonaccorsi $G$, Greco P, et al. Tracing males from different continents by genotyping JC polyomavirus in DNA from semen samples. I Cell Physiol 2017;232(5):982-5.

14. Sroller V, Hamsikova E, Ludvikova V, Vochozkova P, Kojzarova $M$, Fraiberk $M$, et el. Seroprevalence rates of $B K V, J C V$, and MCPyV polyomaviruses in the general Czech Republic population. J Med Virol 2014;86(9):1560-8.

15. Egli A, Infanti L, Dumoulin A, Buser A, Samaridis J, Stebler $C$, et al. Prevalence of polyomavirus BK and JC infection and replication in 400 healthy blood donors. I Infect Dis 2009;199(6):837-46.

16. Us $D$, Hayran $M$, Ustacelebi S. New human polyomavirus; $B K$ virus antibody levels in different age groups using the hemagglutination inhibition test. Mikrobiyol Bul 1991;25(2):173-7 (in Turkish).

17. Olsson T, Achiron A, Alfredsson L, Berger T, Brassat D, Chan $A$, et al. Anti-JC virus antibody prevalence in a multinational multiple sclerosis cohort. Mult Scler 2013;19:1533-88.

18. World Health Organization (WHO). Laboratory Manual For The Examination And Processing Of Human Semen. 5th ed. Geneva: WHO Press, 2010.

19. Schuppe H-C, Pilatz A, Hossain H, Diemer T, Wagenlehner $F$, Weidner W. Urogenital infection as a risk factor for male Infertility. Deutsch Ärzteblatt Intern 201 7;114(19):339-46.

20. Agarwal A, Mulgund A, Hamada A, Chyatte MR. A unique view on male infertility around the globe. Reprol Biol Endocrinol 2015;13:37-46.

21. Papa N, Zanotta N, Knowles A, Orzan E, Comar M. Detection of Malawi polyomavirus sequences in secondary lymphoid tissues from Italian healthy children: a transient site of infection. Virol J 2016;13(1):97-103.

22. Hirsch HH, Steiger J. Polyomavirus BK. Lancet Infect Dis 2003;3(10):611-23.
23. Dolei A, Pietropaolo V, Gomes E, Taranto CD, Ziccheddu M, Spanu MA, et al. Polyomavirus persistence in lymphocytes: prevalence in lymphocytes from blood donors and healthy personnel of a blood transfusion centre. I Gen Virol 2000;81:1967-73.

24. Rota S, Fidan K, Bozdayı G, Dalgıç A, Fidan I, Sucak G, et al. Investigation of $B K$ and JC virus DNA positivities by real-time polymerase chain reaction in the clinical samples of patients with high risk. Mikrobiyol Bul 2011;45(2):280-7 (in Turkish).

25. Cağlı R, Zeytioğlu A, Töz H, Sipahi S, şen S, Seröz R. Detection of polyomavirus (BK and JC virus) DNA with real-time pcr in renal transplant recipients. FLORA 2016;21(3):11623 (in Turkish).

26. Colak $M$, Altay A, Erten Y, Özkurt ZN, Özkan S, Pinar A, et al. Investigation of $B K$ and JC virus DNA positivities by real-time polymerase chain reaction in immunosuppressive patients. Türk Mikrobiyol Cem Derg 2015;45(1):12-21 (in Turkish).

27. Boothpur R, Brennan DC. Human polyoma viruses and disease with emphasis on clinical BK and JC. I Clin Virol 2010;47(4):306-12.

28. Eraksoy M, Agan K, Ak F, Anlar O, Balcı B, Boz C, et al. Anti-John Cunningham Virus antibody prevalence in multiple sclerosis patients in Turkey. J Exp Clin Med 2014;31(1):31-6.

29. Chattaraj S, Bera N, Dutta C, Bhattacharjee S. Quantification of human polyomavirus $\mathcal{C} C$ virus load in urine and blood samples of healthy tribal populations of North-Eastern part of West Bengal, India. Indian I Med Microbiol 2015;33(4):491-5.

30. Enam S, Del Valle L, Lara C, Gan D, Ortiz-Hidalgo C, Palazzo JP, et al. Association of human polyomavirus JCV with colon cancer: evidence for interaction of viral T-antigen and beta-catenin. Cancer Res 2002;62(23):7093-101.

31. Ksiaa F, Allous A, Ziadi S, Mokni M, Trimeche M. Assessment and biological significance of $J C$ polyomavirus in colorectal cancer in Tunisia. J BUON 2015;20(3):762-9.

32. Garolla A, Toni $L D$, Bottacin A, Valente U, Rocco Ponce MD, Di Nisio A, et al. Human Papillomavirus prophylactic vaccination improves reproductive outcome in infertile patients with HPV semen infection: a retrospective study. Scientific Reports 2018;8:912.

\section{Address for Correspondence/Yazıșma Adresi}

\section{Dr. Öğr. Üyesi Fatma ESENKAYA TAȘBENT}

Necmettin Erbakan Üniversitesi Meram Tıp Fakültesi,

Tıbbi Mikrobiyoloji Anabilim Dalı,

Konya-Türkiye

E-mail: fesentas@hotmail.com 